\title{
Analisis Yuridis Peraturan Menteri Keuangan Nomor 130/Pmk.010/2012 dan Peraturan Pemerintah Republik Indonesia Nomor 21 Tahun 2015 Terkait Kewajiban Pendaftaran Fidusia
}

\author{
Ernawati, Bambang Winarno, Siti Noer Endah. \\ Fakultas Hukum Universitas Brawijaya \\ erna.wati97599@gmail.com
}

\begin{abstract}
Abstrak
Jaminan Fidusia lahir karena perkembangan sosial ekonomi masyarakat atas kebutuhan modal dan menjadi salah satu solusi jaminan pinjaman bergerak yang dianggap mampu memacu pertumbuhan ekonomi kecil. Untuk menjamin kepastian hukum pemerintah mengatur dalam Undang-undang Jaminan Fidusia dan pelaksanaanya diatur didalam Peraturan Menteri Keuangan Nomor 130/PMK.010.2012 dengan Peraturan Pemerintah Nomor 21 Tahun 2015. Terkait Dengan Kewajiban Pendaftaran Jaminan Fidusia. Latar belakang lahirnya Peraturan Menteri Keuangan Nomor 130/PMK.010/2012 karena banyaknya perusahaan pembiayaan yang tidak mendaftarkan jaminan fidusia tepat waktu melainkan saat pembiayaan mulai dianggap macet, Padahal lahirnya kreditor yang memiliki hak preferen juga hak eksekutorial yaitu pada saat jaminan fidusia itu didaftarkan. karena ulah perusahaan pembiayaan itu negara juga kehilangan Pendapatan dari Penerimaan Negera Bukan Pajak (PNBP). Sehingga Muncullah Peraturan Pemerintah Nomor 21 Tahun 2015 untuk menunjang pelaksanaan Peraturan Menteri Keuangan Nomor 130/PMK.010/2015 serta aturan pelaksana undang-undang jaminan fidusia.
\end{abstract}

\section{Kata Kunci : Kepastian Hukum, Fidusia, Pendaftaran Fidusia}

\section{Pendahuluan}

Indonesia adalah Negara hukum, hal ini sejalan dengan prinsip yang dijelaskan pada UUD NRI 1945 pasal 1 ayat 3. Dalam penerapan hukum, ada subjek yang terlibat ${ }^{1}$. Namun, disisi lain ada pembatasan

${ }^{1}$ Pada pasal 28 D ayat 1 UUD NRI 1945 menyebutkan, bahwa setiap orang berhak atas pengakuan, jaminan, perlindungan dan kepastian hukum yang adil serta perlakuan sama di hadapan hukum dari hak yang diakui yaitu hak orang lain $^{2}$.

Hukum berwujud perintah dan larangan sehingga sifatnya setiap

${ }^{2}$ Hal ini dijelaskan pada pasal $28 \mathrm{~J}$ UUD NRI 1945 yaitu dalam menjalankan hak dan kebebasannya, setiap orang wajib tunduk kepada pembatasan yang ditetapkan dengan UU dengan maksud semata-mata untuk menjamin pengakuan serta penghormatan atas hak dan kebebasan orang lain, dan untuk memenuhi tuntutan yang adil sesuai dengan pertimbangan moral, nilai nilai agama, keamanan dan ketertiban umum dalam suatu masyarakat demokratis 
orang harus menjalankan perintah dan mentaati larangan hukum. Eksistensi hukum akan menjadi rambu-rambu yang menggariskan aturan main (rule of game) bagi setiap masyarakat tanpa kecuali, agar perilaku dan konstruksi sosial, politik, ekonomi, keagamaan, budaya dan aspek-aspek kehidupan lainnya berjalan di jalur yang benar. Aturan hukum harus ditegakkan agar masing-masing pihak dalam kehidupan bermasyarakat dan bernegara dapat menikmati kehidupan damai, aman dan tertib, tidak saling mengganggu dan merugikan antara satu dan lainnya.

Perkembangan sosial ekonomi masyarakat atas kebutuhan modal usaha serta jaminan kepastian dan perlindungan lembaga keuangan, mendorong pemerintah mengeluarkan regulasi yang mengatur tentang pinjaman yang secara pelaksanaannya memudahkan geliatnya perekonomian mikro kecil dengan nilai penjaminan yang tidak begitu besar dan kebendaan jaminan yang mudah seperti halnya kendaraan atau mesin-mesin usaha. Penyaluran kredit merupakan kegiatan yang beresiko bagi bank dan badan pembiayaan non bank oleh karena itu perlu diimbangi dengan adanya ketentuan hukum jaminan yang jelas dan lengkap, mengingat setiap penyaluran kredit memerlukan jaminan yang kuat.

Dengan dibuatnya UndangUndang No. 42 Tahun 1999 tentang Jaminan Fidusia ini dimaksudkan untuk membantu kegiatan usaha dan untuk memberikan kepastian hukum kepada para pihak yang berkepentingan, terutama dalam dunia perbankan. Fidusia menjadi salah satu solusi jaminan pinjaman, dimana lahirnya fidusia sangat membantu kebutuhan masyarakat dalam mempermudah pengajuan pinjaman, bagi calon debitor yang tidak mempunyai jaminan yang bernilai besar seperti halnya aset utama contohnya rumah (jaminan tidak bergerak). Karena jika calon debitor butuh modal sedangkan asset yang dimiliki hanya kebendaan bergerak contoh kendaraan, mesinmesin sedangkan asset seperti halnya rumah masih mengkontrak maka lahirnya Fidusia sangat membantu 
keterbatasan masyarakat dalam kebutuhan kredit.

Dengan meningkatnya ekonomi masyarakat, maka fidusia selain berkembang dalam pembiayaan untuk pembelian barang-barang modal seperti mesin-mesin, fidusia juga berkembang untuk pembiayaan konsumtif, seperti pembiayaan pembelian kendaraan bermotor, baik mobil maupun sepeda motor.

Fidusia tidak ada diatur dalam Kitab Undang-undang Hukum Perdata, dan lahir dari pelaksanaan asas kebebasan berkontrak yang diatur dalam Pasal 1338 Kitab Undang-Undang Hukum Perdata. ${ }^{3}$

Latar belakang lahirnya lembaga fidusia adalah karena adanya kebutuhan dalam praktek. Kebutuhan tersebut didasarkan atas fakta-fakta bahwa menurut sistem hukum kita

3 yang menyatakan bahwa segala sesuatu perjanjian yang dibuat adalah sah bagi para pihak yang membuatnya dan berlaku sebagai undang-undang bagi yang membuatnya". Artinya setiap orang diperbolehkan membuat perjanjian apa saja baik yang sudah diatur dalam undangundang maupun belum diatur dalam undangundang, sehingga banyak muncul perjanjianperjanjian dalam bentuk baru yang menggambarkan maksud dan kehendak masyarakat yang selalu dinamis. Nurwidiatmo, 2011, Kompilasi Bidang Hukum Tentang Leasing, BPHN, Jakarta, hal 2 jika yang menjadi objek jaminan utang adalah benda bergerak, maka jaminannya diikat dalam bentuk gadai dimana objek jaminan tersebut harus diserahkan kepada pihak yang menerima gadai (kreditor). Sebaliknya, jika yang menjadi objek jaminan utang adalah benda tak bergerak, maka jaminan tersebut haruslah berbentuk hipotik (sekarang ada hak tanggungan) yang mana objek jaminan tidak diserahkan kepada kreditor , tetapi tetap dalam kekuasaan debitor.

Jaminan fidusia adalah " hak jaminan atas benda bergerak baik yang berwujud maupun yang tidak berwujud dan benda tidak bergerak khususnya bangunan yang tidak dapat dibebani hak tanggungan sebagaimana yang dimaksud dalam UU No 4 tahun $1996^{4}$ tentang hak tanggungan yang tetap berada dalam penguasaan pemberi fidusia, sebagai agunan bagi pelunasan hutang tertentu, yang memberikan kedudukan yang diutamakan kepada penerima fidusia terhadap kreditor

\footnotetext{
${ }^{4}$ Untuk selanjutnya disebut UUJF
} 
lainnya".5 Sedangkan pengertian fidusia itu sendiri adalah " Pengalihan hak kepemilikan suatu benda atas dasar kepercayaan dengan ketentuan bahwa benda yang hak kepemilikannya dialihkan tersebut tetap dalam penguasaan pemilik benda". 6

Setelah dikeluarkannya UUJF, dunia jaminan fidusia semakin menarik perhatian para pelaku bisnis pembiayaan dan kalangan perbankan.

Karena semula hanya berdasarkan yurisprudensi yang tidak memberikan perlindungan hukum bagi para pihak dan diharapkan pada saat dikeluarkannya UU tersebut lebih memberikan perlindungan hukum para pihak dan kepastian hukum. Namun di sisi lain, masih terdapat beberapa kelemahan dari UUJF tersebut, dimana kurang memberikan perlindungan hukum dan kepastian hukum. Sehingga dirasakan belum sepenuhnya terwujud sebagaimana yang diharapkan dalam UUJF.

Kendala-kendala yang timbul dalam pelaksanaan UUJF selama ini

5 Undang-Undang Nomor 42 Tahun 1999 tentang Jaminan Fidusia

${ }^{6}$ Ibid menunjukkan kurangnya penegakan hukum dalam pelaksanaan UndangUndang tersebut di atas. Kajian terhadap aturan hukum ini menyimpulkan hal-hal yang positif dan negatif. Hal yang bersifat positif dapat merupakan masukan konstruktif untuk pembaharuan hukum (law reform) di masa datang (ius constituendum). Yang bersifat negatif berupa penyimpangan hukum (legal deviation) yang tidak dapat dipertanggung jawabkan. UUJF banyak mengandung kelemahankelemahan antara lain :

1) Rawan terjadi fidusia ulang, dan berpotensi konflik karena tidak ada jangka waktu pendaftaran.

2) Tidak ada sanksi yang tegas terhadap pengikatan jaminan fidusia yang tidak dilakukan secara Notariil.

3) Tidak ada larangan kuasa menjaminkan. Menyebabkan maraknya pengunaan kuasa menjaminkan secara di bawah tangan untuk menunda pendaftaran jaminan fidusia, sehingga berpotensi konflik juga mengingat terkait dengan keabsahan tanda tangan dalam 
kuasa tersebut, kecuali dilegalisasi oleh Notaris atau dibuat kuasa notarial.

4) Tidak ada sanksi yang tegas terhadap penggunaan "kuasa jual” yang jelas-jelas bertentangan dengan cara-cara eksekusi sesuai UU No.42 Tahun 1999 sehingga berpotensi tidak memberikan rasa keadilan bagi debitor. Adapun larangan membuat kuasa menjual yang dibarengi dengan Perjanjian Kredit adalah berdasarkan putusan Mahkamah Agung tanggal 29 Juli 1987 Nomor Reg.3309k/PDT/1985 dan Putusan Mahkamah Agung tanggal 31 Mei 1990 Nomor 1726k/PDT/1986. Pelanggaran terhadap Putusan Mahkamah Agung tersebut menjadikan kuasa menjual tersebut batal demi hukum.

Dalam Konsiderans UUJF antara lain dirumuskan bahwa keberadaan UU tentang Jaminan Fidusia diharapkan memberikan kepastian hukum dan memberikan perlindungan hukum bagi yang berkepentingan dan jaminan tersebut "perlu" didaftarkan di Kantor Pendaftaran Jaminan Fidusia. Penggunaan kata-kata "perlu,wajib" mengandung sifat ambigu/kemenduaan (ambiguity) dan multitafsir yang jauh dari prinsip kepastian hukum (legal certainty,lex certa).

Keragu-raguan tentang wajib atau tidaknya pendaftaran tersebut diperkuat dengan kendala tidak adanya batasan jangka waktu pendaftaran jaminan fidusia di Kantor Pendaftaran Jaminan Fidusia. Pada akhirnya akibat dari keraguraguan dan kurang jelasnya peraturan yang mengatur secara detail membuat banyak perusahaan pembiayaan yang tidak mendaftarkan jaminan fidusia. Hal tersebut akan mengurangi kepercayaan para pelaku bisnis khususnya kreditor sebab sifat spesialitas dan publisitas serta hak preferent (droit de preference) atau hak untuk didahulukan terhadap kreditor lain pasti mengalami kendala dan apabila debitor wanprestasi serta berpotensi "fidusia ulang".

Setelah banyaknya ambiguitas atas UUJF maka muncullah 
Permenkeu No.130/PMK.010/2012 ${ }^{7}$.

Pada dasarnya Peraturan Menteri tersebut mengatur mengenai kewajiban pendaftaran jaminan fidusia dalam jangka waktu tertentu. Kewajiban tersebut hanya dibebankan kepada perusahaan pembiayaan konsumen yang melakukan pembiayaan kendaraan bermotor $^{8}$. Berdasarkan ketentuan Pasal 2. Bunyinya " Perusahaan Pembiayaan wajib mendaftarkan jaminan fidusia pada Kantor Pendaftaran Fidusia paling lama 30 (tiga puluh) hari kalender terhitung sejak tanggal perjanjian pembiayaan konsumen"9.

Selain mengatur kewajiban tersebut, Permenkeu tersebut juga mengatur sejumlah sanksi terhadap perusahaan pembiayaan yang tidak melaksanakan kewajiban tersebut sebagaimana diatur dalam Pasal 5

\footnotetext{
${ }^{7}$ Untuk selanjutnya disebut Permenkeu sebagaimana ditegaskan dalam ketentuan Pasal 1. Bunyinya " Perusahaan Pembiayaan yang melakukan pembiayaan konsumen untuk kendaraan bermotor dengan pembebanan jaminan fidusia wajib mendaftarkan jaminan fidusia dimaksud pada kantor pendaftaran fidusia, sesuai undang-undang yang mengatur mengenai jaminan fidusia" Peraturan Menteri Keuangan Republik Indonesia No.130/PMK.010/2012$$
{ }^{9} \text { Ibid }
$$

ayat (1) antara lain berupa: peringatan, pembekuan kegiatan usaha atau pencabutan izin usaha. Pada dasarnya pengaturan kewajiban pendaftaran ini baik untuk menjamin hak preferen kreditor dan menjamin kepastian hukum bagi pihak ketiga. Namun larangan ini hanya berlaku bagi perusahaan pembiayaan. Padahal praktik demikian tidak hanya dijalankan oleh perusahaan pembiayaan tetapi juga oleh lembaga perbankan.

Keberadaan Permenkeu setidaktidaknya telah membawa angin segar juga dalam dunia jaminan fidusia dengan diaturnya hal-hal sebagai berikut ;

1) Menekankan ketentuan wajib mendaftarkan jaminan fidusia di Kantor Pendaftaran Fidusia.

2) Menegaskan jangka waktu pendaftaran merupakan langkah untuk menjamin kepastian hukum.

3) Menekan tindakan yang bertentangan dengan rasa keadilan dengan mengatur masalah tata cara penarikan benda jaminan fidusia. 
4) Penerapan sanksi yang tegas terhadap pelanggaran ketentuan tersebut sangat diperlukan sebagai upaya paksa juga untuk pelaksanaan pendaftaran obyek jaminan fidusia.

5) Lebih memberikan rasa keadilan karena dengan dilaksanakan Pendaftaran obyek jaminan fidusia, maka apabila debitor wanprestasi akan ditempuh caracara eksekusi sesuai UU No.42 Tahun 1999.", 10

Namun disisi lain, adanya Peraturan Menteri Keuangan Republik Indonesia Nomor 130/PMK.010/2012 masih menimbulkan beberapa kendala antara lain :

1) Debitur akan terbebani dengan tambahan biaya pembuatan akta jaminan fidusia secara Notariil berikut biaya pendaftarannya.

2) Debitur Perusahaan Pembiayaan yang terletak di pelosok-pelosok akan sulit melaksanakan penandatangan dihadapan Notaris karena letaknya jauh dari tempat tinggal debitur.

\footnotetext{
${ }^{10}$ Ibid
}

3) Kantor Pendaftaran Jaminan Fidusia yang belum sampai ke pelosok-pelosok daerah.

4) Penggunaan kuasa menjaminkan secara di bawah tangan rawan akan keabsahan tanda tangannya, dan tidak semua Notaris bersedia untuk menuangkan dalam Akta Notariil.

5) Berpengaruh terhadap omzet penjualan karena ada beban tambahan biaya dan teknis penandatanganan akta secara Notariil.

Kebijakan keluarnya Permenkeu berbuntut kepada lonjakan pendaftaran fidusia sampai tiga kali lipat pada kantor-kantor pendaftaran fidusia.Terjadi Tunggakan pendaftaran fidusia luar biasa pada kantor-kantor pendaftaran fidusia sepanjang akhir tahun 2012, selanjutnya Kemenhumham terus melakukan penyempurnaan. Kuartal pertama tahun 2015 pemerintah telah mengeluarkan Peraturan Pemerintah Nomor 21 tahun 2015 tentang Tata Cara Pendaftaran Jaminan Fidusia Dan Biaya Pembuatan Akta Jaminan Fidusia. Bedasarkan latar belakang diatas 
dapat dirumuskan suatu masalah yaitu Bagaimana Implikasi Yuridis dengan perwujudan Peraturan Menteri Keuangan Nomor 130/PMK.010/2012 dan Peraturan Pemerintah Republik Indonesia Nomor 21 Tahun 2015 terkait dengan kewajiban pendaftaran fidusia.

\section{Tujuan Penelitian}

Adapun tujuan penelitian ini adalah : Untuk mengetahui Implikasi Yuridis dengan perwujudan Peraturan Menteri Keuangan Nomor 130/PMK.010/2012 dan Peraturan Pemerintah Republik Indonesia Nomor 21 Tahun 2015 terkait dengan kewajiban pendaftaran Fidusia.

\section{Metode}

Penelitian ini merupakan penelitian hukum (Legal Research), yang merupakan serangkaian tindakan atau proses untuk menemukan hukum disebabkan terjadinya kekosongan hukum (vacuum norm), kekaburan norm (obscuur norm) maupun konflik norm (conflict of norm) atau menemukan asas hukum, yang mengatur norma hukum yang mengikat secara umum dan dibentuk atau ditetapkan oleh lembaga atau pejabat yang berwenang melalui prosedur yang ditetapkan dalam peraturan perundang-undangan, khususnya yang berkenaan dengan norma yang mengatur mengenai pendaftaran fidusia.

\section{Pembahasan}

Menurut UUJF, Perjanjian Jaminan Fidusia dilakukan melalui dua tahap yaitu tahap pembebanan dan tahap pendaftaran jaminan fidusia. Serta yang dapat menjadi objek jaminan fidusia adalah benda bergerak maupun yang tidak bergerak dan benda-benda lain yang tidak dapat dibebani oleh jaminan hak tanggungan. Berdasarkan Pasal 5 ayat (1) Undang-Undang Jaminan Fidusia disebutkan bahwa pembebanan benda dalam Jaminan Fidusia dibuat dengan akta notaris dalam bahasa Indonesia dan merupakan akta Jaminan Fidusia. Dalam Pasal 1868 KUHPerdata menyebutkan suatu akta otentik adalah suatu akta yang dibuat dalam bentuk yang 
ditentukan oleh Undang-undang, dibuat oleh dan dihadapan Pejabat Umum yang berkuasa untuk itu dimana akta tersebut dibuat. Maka dari itu akta notaris merupakan salah satu bentuk akta otentik.

Adapun syarat-syarat untuk membuat akta Fidusia adalah :

1) Apabila debitornya perorangan :

a) Identitas debitor

b) Identitas kreditor

c) NPWP debitor dan kreditor

d) Surat Perjanjian Kredit dari bank

e) BPKB dan STNK dari Barang yang akan difidusiakan

2) Apabila debitornya perusahaan :

a) Akta Perusahaan;

b) Identitas pengurus perusahaan yaitu kalau CV adalah Persero Pengurus dan Persero Komanditer, apabila berbentuk PT adalah direksi dan komisaris.

c) NPWP pengurus perusahaan dan perusahaan

d) Surat Perjanjian Kredit dari bank e) BPKB dari Barang yang akan difidusiakan Invoice untuk alat-alat berat.

Setelah semua persyaratan terpenuhi, maka dituangkan dalam bentuk akta dan ditandatangani oleh para penghadap yaitu kreditor dan debitor. Apabila tahapan pembebanan telah dilaksanakan maka akta jaminan fidusia tersebut wajib didaftarkan ${ }^{11}$.

Pendaftaran Jaminan Fidusia akan melahirkan hak kebendaan, sehingga kedudukan kreditor menjadi kreditor preferen dengan segala hak istimewa yang diberikan oleh undang-undang. Oleh karena pendaftaran tersebut secara tidak langsung memberikan manfaat bagi pihak kreditor, maka kewajiban pendaftaran berlaku pada pihak penerima fidusia (kreditor) sedangkan debitor tidak memiliki kepentingan atas didaftarkan atau tidaknya jaminan tersebut, bahkan debitor akan lebih diuntungkan

\footnotetext{
${ }^{11}$ hal ini berdasarkan ketentuan Pasal 11 ayat (1) Undang-Undang Nomor 42 Tahun 1999 Tentang Jaminan Fidusia bahwa benda yang dibebani dengan jaminan fidusia wajib didaftarkan
} 
seandainya benda yang diserahkan sebagai jaminan fidusia tidak didaftarkan oleh pihak kreditor.

Selain oleh pihak penerima fidusia sendiri, pendaftaran dapat diwakilkan kepada kuasa atau wakilnya yang ditunjuk secara sah oleh penerima fidusia ${ }^{12}$. Namun Pendaftaran Jaminan Fidusia ini terdapat kelemahan dalam praktek pelaksanaannya yang dinilai kurang praktis dan prosesnya memakan waktu yang lama sehingga berakibat mengabaikan peraturan bahwa objek jaminan fidusia harus di daftarkan di Kantor Pendaftaran Fidusia.

$$
\text { Menyangkut tata cara }
$$
pendaftaran jaminan fidusia ini telah mengalami perubahan alur proses yaitu dari manual proses menjadi online proses pada tahap pendaftaran hingga tahap pembayarannya dilakukan secara elektronik (online). Hal ini diawali

12 Tata cara pendaftaran jaminan fidusia yang dilakukan oleh penerima fidusia diatur dalam Undang-Undang Nomor 42 Tahun 1999 Tentang Jaminan Fidusia diatur pada Pasal 11 sampai dengan Pasal 18 serta tata cara pendaftaran fidusia ini juga diatur lebih lanjut dalam Peraturan Pemerintah Nomor 86 Tahun 2000 Tentang Tata Cara Pendaftaran Jaminan Fidusia. $\begin{array}{lrr}\text { dengan } & \text { munculnya } & \text { Peraturan } \\ \text { Menteri } & \text { Keuangan } & \text { Nomor } \\ \text { 130/PMK.010/2012 } & \text { Tentang }\end{array}$

Pendaftaran Jaminan Fidusia Bagi

Perusahaan Pembiayaan Yang

Melakukan Pembiayaan Konsumen

Untuk Kendaraan Bermotor dengan Pembebanan Jaminan Fidusia, yaitu pada Pasal 2 menyebutkan bahwa Perusahaan Pembiayaan wajib mendaftarkan jaminan fidusia pada Kantor Pendaftaran Fidusia paling lama 30 (tiga puluh) hari kalender terhitung sejak tanggal perjanjian pembiayaan konsumen, maka tentunya hal ini membuat para pelaku perusahaan pembiayaan melakukan pendaftaran jaminan fidusia yang jumlahnya tentu tidak sedikit diseluruh Indonesia kepada notaris. Sehingga guna menanggulangi hal tersebut melalui Surat Edaran Dirjen AHU, nomor AHU-06.OT.03.01 tahun 2013 tentang Pemberlakuan Sistem Administrasi Pendaftran Jaminan Fidusia secara Elektronik (Online System) maka terhitung sejak tanggal 5 Maret 2013, Kantor Pendaftaran Fidusia tidak lagi menerima pendaftaran jaminan 
fidusia secara manual dikarenakan telah diterbitkannya sistem online dalam melakukan pendaftaran jaminan fidusia yang dapat diakses melalui kantor-kantor notaris di seluruh Indonesia yang telah terdaftar dan memiliki username dan password yang bersifat rahasia.

\begin{tabular}{llr}
\multicolumn{1}{c}{ Dengan } & keluarnya & Peraturan \\
Menteri & Keuangan & nomor \\
130/PMK 010/2012 &
\end{tabular}
130/PMK.010/2012

tentang Pendaftaran Jaminan Fidusia bersifat "wajib" Bagi Perusahaan Pembiayaan Yang melakukan Pembiayaan Konsumen untuk kendaraan bermotor dengan pembebanan jaminan fidusia. Pada intinya mewajibkan semua Perusahaan Pembiayaan Non Bank dalam pembiayaan kendaraan bermotor untuk mendaftarkan jaminan Fidusia yang telah mereka pungut biayanya ke KPF paling lama 30 hari sejak perjanjian Pembiayaan dengan konsekuensi larangan untuk melakukan eksekusi dalam hal kegagalan bayar (default), apabila belum terbit sertipikat jaminan fidusia dan pencabutan izin usaha perusahaan pembiayaan tersebut apabila jaminan fidusia tidak didaftarkan.

Kebijakan ini telah berakibat kepada lonjakan jumlah pendaftaran Fidusia sampai tiga kali lipat pada Kantorkantor pendaftaran Fidusia. Terjadi tunggakan pendaftaran Fidusia luar biasa pada kantor-kantor pendaftaran Fidusia sepanjang kuartal akhir tahun 2012. Karena perusahaan pembiayaan yang selama ini mengabaikan kewajiban pendaftaran dipaksa untuk melakukan pendaftaran. Situasi ini berlangsung sampai Februari 2013, ketika Kementerian Hukum dan HAM akhirnya meluncurkan pendaftaran Fidusia secara online sebagai pengganti sistem manual.

Melalui Permenkumham 8/2013 tentang Pendelegasian Penandatanganan Sertifikat Jaminan Fidusia Secara Elektronik, Permenkumham 9/2013 tentang Pemberlakuan Pendaftaran Jaminan Fidusia Secara Elektronik, Permenkumham 10/2013 tentang Tata Cara Pendaftaran Jaminan Fidusia Secara Elektronik dan SE Dirjen AHU No AHU-06.OT.03.01 Tahun 2013 tentang Operasionalisasi 
Sistem Pendaftaran Fidusia Elektronik (online) pendaftaran Fidusia telah sepenuhnya dilakukan secara online, dan menutup lembaran pendaftaran Fidusia manual ke dalam khazanah sejarah. Pasca Fidusia Online, waktu yang diperlukan untuk melakukan pendaftaran Fidusia dipotong menjadi hanya 7 menit. Selanjutnya, Kemenkumham terus melakukan penyempurnaan. Kuartal pertama 2015 pemerintah telah mengesahkan Peraturan Pemerintah Nomor 21 Tahun 2015 tentang Tata Cara Pendaftaran Jaminan Fidusia Dan Biaya Pembuatan Akta Jaminan Fidusia yang merubah PP 86 Tahun 2000. Pemerintah juga telah mengatur kembali Tarif PNBP Fidusia melalui Peraturan Pemerintah Nomor 10 Tahun 2015 yang antara lain menghapuskan PNBP bagi pencabutan pendaftaran, yang diharapkan mendorong kepatuhan pemberi Fidusia untuk melakukan pencabutan.

Selain itu, fasilitas Fidusia Online sendiri telah menjalani setidaknya satu kali penyempurnaan. Pada September 2014 dalam kerangka AHU online, sistem
Fidusia Online baru yang memuat informasi lebih komprehensif diluncurkan oleh Ditjen AHU Kemenkumham. Sistem Fidusia Online yang dimutakhirkan tersebut memuat lebih banyak informasi dan memungkinkan dilakukannya penelusuran informasi sederhana terhadap database Fidusia.

Melalui cara baru ini, pelayanan jasa hukum di bidang fidusia diharapkan lebih cepat, akurat dan bebas pungutan liar dalam mengurus pendaftaran jaminan fidusia serta bertujuan agar seluruh pendaftaran jaminan fidusia dapat terdata secara nasional dalam database Ditjen AHU sehingga asas publisitas meningkat. Berkenaan dengan tata cara pendaftaran jaminan fidusia online kemudian pada tanggal 6 April 2015 diundangkan Peraturan Pemerintah Nomor 21 Tahun 2015 Tentang Tata Cara Pendaftaran Jaminan Fidusia Dan Biaya Pembuatan Akta Jaminan Fidusia yang menggantikan Peraturan Pemerintah Nomor 86 Tahun 2000 Tentang Tata Cara Pendaftaran Jaminan Fidusia Dan 
Biaya Pembuatan Akta Jaminan Fidusia.

Dalam peraturan pemerintah yang baru ini juga adanya Penetapan Resmi Standard biaya pembuatan akta jaminan fidusia. Pembuatan akta Jaminan Fidusia dikenakan biaya yang besarnya ditentukan berdasarkan nilai penjaminan ${ }^{13}$. Pada Peraturan Pemerintah Nomor 21 Tahun 2015 Tentang Tata Cara Pendaftaran Jaminan Fidusia Dan Biaya Pembuatan Akta Jaminan Fidusia terdapat beberapa aturan baru yang telah disesuaikan dengan perkembangan, antara lain :

1) Adanya ketentuan jangka waktu pendaftaran jaminan fidusia yaitu akta jaminan fidusia harus segera didaftarkan secara online dalam jangka

\footnotetext{
${ }^{13}$ Ketentuan tercantum pada Pasal 18 dengan ketentuan sebagai berikut : 1) nilai penjaminan sampai dengan Rp100.000.000,00 (seratus juta rupiah), biaya pembuatan akta paling banyak 2,5\% (dua koma lima perseratus), 2) nilai penjaminan di atas Rp100.000.000,00 (seratus juta rupiah) sampai dengan Rp1.000.000.000,00, (satu miliar rupiah), biaya pembuatan akta paling banyak 1,5\% (satu koma lima perseratus); dan nilai penjaminan di atas Rp1.000.000.000,00 (satu miliar rupiah), biaya pembuatan akta berdasarkan kesepakatan antara notaris dengan para pihak, tetapi tidak melebihi $1 \%$ (satu perseratus) dari objek yang dibuatkan aktanya.
}

waktu paling lama 30 hari terhitung sejak tanggal pembuatan akta jaminan fidusia.

2) Adanya kewajiban bagi para Penerima Fidusia, kuasa atau wakilnya untuk memberitahukan penghapusan Jaminan Fidusia serta pemberitahuan ini juga diatur jangka waktunya yaitu wajib memberitahukan kepada Menteri dalam jangka waktu paling lama 14 (empat belas) hari terhitung sejak tanggal hapusnya Jaminan Fidusia. Pemberitahuan penghapusan fidusia ini tidak dikenakan biaya, maka dengan tidak adanya biaya yang dikenakan diharapkan para Penerima Fidusia, kuasa atau wakilnya dapat segera melakukan pemberitahuan penghapusan Jaminan Fidusia tersebut.

3) Besarnya biaya pembuatan akta Jaminan Fidusia ditentukan berdasarkan nilai penjaminan yang mengacu pada besarnya biaya pembuatan akta yang diatur dalam Pasal 36 ayat (3) Undang-Undang Nomor 30 Tahun 2004 tentang 
Jabatan Notaris yang saat ini undang-undang tersebut telah diubah dengan Undang-Undang Nomor 2 Tahun 2014 tentang Perubahan atas Undang-Undang Nomor 30 Tahun 2004 tentang Jabatan Notaris.

4) Adanya ketentuan yaitu seluruh data yang diisi dalam Permohonan Pendaftaran Jaminan Fidusia, Permohonan Perbaikan Sertifikat Jaminan Fidusia, Permohonan Perubahan Sertifikat Jaminan Fidusia, serta Pemberitahuan Penghapusan Sertifikat Jaminan Fidusia secara elektronik dan penyimpanan dokumen fisiknya menjadi tanggung jawab Penerima Fidusia, kuasa atau wakilnya.

Disisi lain berkenaan dengan hapusnya jaminan fidusia adalah tidak berlakunya lagi jaminan fidusia tersebut. Hal ini sesuai dengan arti kata hapus menurut KBBI bahwa penghapusan berasal dari kata hapus yang berarti tidak terdapat atau tidak terlihat lagi, hilang, musnah, lenyap atau diampuni. Terdapat beberapa penggunaan istilah dalam peraturan perundang-undangan tentang jaminan fidusia yang pada intinya mempunyai satu maksud yang sama, yaitu agar jaminan fidusia yang terdaftar dapat dihilangkan dari buku daftar fidusia.

Pengaturan penghapusan jaminan fidusia dapat ditemukan dalam Undang-Undang Jaminan Fidusia Nomor 42 tahun 1999 dan Peraturan Pemerintah Nomor 21 Tahun 2015, namun dalam peraturan tersebut memiliki beberapa perbedaan. Dalam Undang-Undang Jaminan Fidusia Nomor 42 tahun 1999 yang disebutkan subjek yang melaksanakan penghapusan adalah penerima fidusia sebagaimana disebutkan dalam pasal 25 ayat ( 3 ) penerima fidusia memberitahukan kepada Kantor Pendaftaran Fidusia mengenai hapusnya jaminan fidusia. Sedangkan dalam Peraturan Pemerintah Nomor 21 Tahun 2015 diatur lain, dalam Pasal 16 ayat (2) kewajiban tersebut tidak hanya dapat dilaksanakan oleh penerima fidusia saja namun juga dapat 
dilaksanakan oleh kuasa atau wakil dari penerima fidusia.

Ketentuan Pasal 16 ayat (2) Peraturan Pemerintah Nomor 21 tahun 2015 menentukan adanya kewajiban kepada penerima fidusia, kuasa atau wakilnya untuk memberitahukan kepada Menteri tentang adanya jaminan fidusia yang hapus.

Ketentuan Peraturan Pemerintah Nomor 21 Tahun 2015 yang memberikan kewajiban untuk melakukan pemberitahuan memang telah memberikan perumusan yang lebih baik dibandingkan dengan perumusan dalam Undang-Undang Jaminan Fidusia yang dinilai tidak memberikan adanya kepastian hukum untuk melakukan penghapusan jaminan fidusia dan seolah-olah hanya bersifat sebagai anjuran untuk memberitahukan kepada KPF tentang hapusnya jaminan fidusia dan bukan sebagai suatu keharusan. Meskipun demikian ternyata dalam Peraturan Pemerintah Nomor 21 Tahun 2015 tidak memberikan sanksi apapun apabila penerima fidusia, kuasa atau wakilnya tidak memberitahukan kepada Kantor Pendaftaran Fidusia. Tidak adanya sanksi yang mengancam menyebabkan penerima fidusia, kuasa atau wakilnya merasa bahwa penghapusan fidusia tidak akan memiliki konsekuensi sekalipun tidak dilakukan.

Menurut pendapat M. Bahsan, “ bahwa penghapusan harus dilakukan terutama terhadap objek dari lembaga jaminan yang sewaktu pembebanannya disyaratkan untuk melakukan kewajiban pendaftaran. Misalnya seperti lembaga jaminan hipotek, hak tanggungan, atau jaminan fidusia". ${ }^{14}$

Proses penghapusan yang paling banyak diketahui oleh masyarakat adalah " pada hak tanggungan, setelah hutangnya lunas maka hak tanggungan hapus dan perlu untuk dilakukan penghapusan ( roya atau pencoretan ) agar tanah yang semula dibebani dengan hak tanggungan menjadi

14 M. Bahsan, Hukum Jaminan dan Jaminan Kredit Perbankan Indonesia, (Jakarta: Raja Grafindo Persada, 2008), hlm. 147. 
bersih dari statusnya sebagai

elektronik memang hanya jaminan" 15

Pada kenyataannya penerima membutuhkan waktu beberapa menit saja, namun seringkali fidusia banyak yang tidak melaksanakan penghapusan jaminan fidusia, karena adanya anggapan apabila utang tersebut telah dilunasi maka akan menjadi hapus demi hukum dan tidak perlu melakukan perbuatan apapun. Pihak dealer juga menyatakan bahwa tidak mengetahui adanya sanksi bahwa apabila belum dilakukan penghapusan, maka akibatnya benda objek jaminan fidusia tersebut tidak dapat didaftarkan kembali. Berdasarkan pelaksanan di lapangan, selama ini pendaftaran jaminan fidusia untuk objek yang belum dilaksanakan penghapusan masih dapat dilakukan dan tidak pernah terjadi penolakan dari sistem fidusia elektronik tersebut.

Pemberian jangka waktu selama 14 (empat belas) hari memang dinilai sangat singkat dibandingkan dengan jangka waktu pendaftaran, yaitu 30 (tiga puluh) hari. Pelaksanaan penghapusan jaminan fidusia dengan cara

\footnotetext{
${ }^{15}$ Ibid hlm. 148.
}

pemberi fidusia tidak mendapatkan edukasi yang cukup tentang adanya keharusan untuk melakukan penghapusan jaminan fidusia sehingga meskipun penerima fidusia telah memberikan surat kuasa tetapi debitor atau pemberi fidusia tidak mengetahui bahwa terdapat kewajiban untuk melakukan penghapusan jaminan fidusia. PP Fidusia hanya mengatur jangka waktu tanpa memberikan sanksi apapun apabila penghapusan jaminan fidusia tidak dilaksanakan setelah 14 (empat belas) hari, sanksi yang paling mungkin adalah bahwa benda yang masih terdaftar dan belum dilakukan penghapusan tersebut tidak dapat didaftarkan kembali sebagaimana dimaksud dalam ketentuan Pasal 17 ayat (2) PP Nomor 21 Tahun 2015 sehingga akibatnya adalah pemberi fidusia sebagai pihak yang dirugikan.

Ketentuan dalam PP Nomore 21 Tahun 2015 memang menyatakan bahwa apabila belum 
dilakukan penghapusan, maka benda objek jaminan tersebut tidak dapat didaftarkan (sekalipun utangnya telah lunas).

Menurut Fred B.G. Tumbuan, sebagaimana yang dikutip oleh Gunawan Widjaja dan Ahmad Yani menyatakan bahwa dengan hapusnya jaminan fidusia, tidak perlu dilakukan pengalihan kembali (retro-overdracht) atas hak kepemilikan yang sebelumnya telah beralih dari pemberi fidusia kepada penerima fidusia. Hal ini sesuai dengan sifat perjanjian tambahan dan perjanjian jaminan fidusia yang mengandung adanya syarat batal di dalamnya. ${ }^{16}$

Syarat batal berdasarkan ketentuan Pasal 1265 KUHPer adalah : "syarat yang apabila dipenuhi, menghentikan perikatan, dan membawa segala sesuatu kembali, pada keadaan semula, seolah-olah tidak pernah ada suatu perikatan". Dengan demikian, jika utang telah dilunasi oleh debitor maka dengan sendirinya hak kepemilikan akan kembali kepada

\footnotetext{
${ }^{16}$ Gunawan Widjaja dan Ahmad Yani, op.cit., hlm. 155.
}

pemberi fidusia. Kedudukan benda memang akan langsung kembali kepada pemberi fidusia, akan tetapi status dari benda objek jaminan tersebut masih tetap terus melekat dan terdaftar dalam buku daftar fidusia atau sistem pendaftaran fidusia sampai ada perbuatan untuk melakukan penghapusan. Termasuk apabila dikemudian hari, benda yang pernah digunakan sebagai objek jaminan tersebut dialihkan kepada pihak lain maka jaminan fidusia dianggap masih tetap berlaku, karena masih berstatus terdaftar. Hal ini sesuai dengan sifat dari jaminan kebendaan yang selalu mengikuti bendanya dan dapat dipertahankan terhadap siapapun, namun terdapat pengecualian dalam hal benda objek jaminan fidusia yang berupa benda persediaan. Sebagaimana ketentuan Pasal 21 UUJF menentukan bahwa benda persediaan yang dijadikan objek jaminan fidusia dapat dialihkan asalkan dengan cara dan prosedur yang lazim dalam bidang perdagangan. 
Sesuai dengan ketentuan dalam Pasal $4 \mathrm{UUJF}^{17}$, perjanjian jaminan fidusia merupakan bentuk perjanjian tambahan atau perjanjian ikutan yang memiliki sifat bergantung pada perjanjian pokoknya. Perjanjian tambahan tidak pernah ada apabila perjanjian pokoknya tidak ada. Dalam hal perjanjian pokoknya telah hapus maka perjanjian tambahan akan ikut hapus, tetapi tidak berlaku yang sebaliknya yaitu hapusnya perjanjian jaminan tidak berarti perjanjian pokok menjadi ikut hapus.

Pengaturan penghapusan jaminan fidusia dapat ditemukan dalam UUJF dan Peraturan Pemerintah Nomor 21 Tahun 2015, namun dalam peraturan tersebut memiliki beberapa perbedaan. Dalam UUJF yang disebutkan subjek yang melaksanakan penghapusan adalah penerima fidusia, sedangkan dalam Peraturan Pemerintah Fidusia diatur lain, dalam Pasal 16 ayat (2) kewajiban tersebut tidak hanya dapat dilaksanakan oleh penerima fidusia

17 Pasal 4 UUJF : jaminan fidusia merupakan perjanjian ikutan dari suatu perjanjian pokok yang menimbulkan kewajiban bagi para pihak untuk memenuhi suatu prestasi. saja namun juga dapat dilaksanakan oleh kuasa atau wakil dari penerima fidusia. setelah dilakukan penghapusan maka harus dilakukan pemberitahuan kepada KPF.

Dalam praktenya Meskipun demikian ternyata dalam Peraturan Pemerintah Fidusia tidak memberikan sanksi apapun apabila penerima fidusia, kuasa atau wakilnya tidak memberitahukan kepada KPF. Tidak adanya sanksi yang mengancam menyebabkan penerima fidusia, kuasa atau wakilnya merasa bahwa penghapusan fidusia tidak akan memiliki konsekuensi sekalipun tidak dilakukan. Pada kenyataannya penerima fidusia banyak yang tidak melaksanakan penghapusan jaminan fidusia, karena adanya anggapan apabila utang tersebut telah dilunasi maka akan menjadi hapus demi hukum dan tidak perlu melakukan perbuatan apapun.

Meskipun biaya penghapusan telah digratiskan, tetapi apabila pemberi fidusia meminta tolong kepada notaris untuk melakukan penghapusan maka tentulah harus mengeluarkan biaya untuk jasa 
notaris. Penghapusan fidusia seharusnya wajib dilakukan sesegera mungkin setelah utangnya lunas dan sebelum objek benda jaminan fidusia tersebut dibebani dengan utang yang lain (dijadikan jaminan utang kembali). Bahkan dalam ketentuan pasal yang sama, yaitu Pasal 16 ayat (2) PP Nomor 21 Tahun 2015 disebutkan bahwa jangka waktu paling lama adalah 14 (empat belas) hari sejak tanggal hapusnya jaminan fidusia. Pengaturan jangka waktu terkait pelaksanaan penghapusan jaminan fidusia juga merupakan hal baru yang tidak diatur sebelumnya dalam UUJF.

\section{Simpulan}

Peraturan Menteri Keuangan Nomor 130/PMK/010.2012 menyatakan Perusahaan pembiayaan wajib mendaftarkan jaminan fidusia pada Kantor Pendaftaran Fidusia paling lama 30 (tiga puluh) hari kerja sejak tanggal perjanjian pembiayaan konsumen”. Apabila dilanggar maka sanksinya bagi perusahaan pembiayaan adalah : Peringatan, Pembekuan kegiatan usaha dan sanksi paling berat berupa
Pencabutan izin usaha, sehingga diharapkan memberi efek jera kepada perusahaan pembiayaan.

Muncullah Peraturan Pemerintah Nomor 21 Tahun 2015 tentang sistem Fidusia online, ini merupakan penyempurnaan pengaturan sistemsistem atau sebagai peraturan pelaksana pendaftaran jaminan fidusia secara sistem online, dari sistem pendaftaran terdahulu yaitu sistem manual. Dimana pendaftaran jaminan fidusia dengan sistem online ini memudahkan notaris dalam melakukan pendaftaran jaminan fidusia serta tidak memakan waktu cukup lama yang mana pendaftaran dapat diselesaikan dalam waktu beberapa menit. Untuk menjamin kepastian hukum kreditor, maka PP Nomor 21 tahun 2015 mengatur jangka waktu pendaftaran jaminan fidusia secara online 30 (tiga puluh) hari sejak ditandatanganinya akta jaminan fidusia.

Penghapusan jaminan fidusia disebabkan karena adanya : (1) Hapusnya utang yang dijamin dengan Fidusia (2) Pelepasan hak atas Jaminan Fidusia oleh Penerima 
Fidusia, atau(3) Musnahnya benda yang menjadi obyek Jaminan Fidusia.

Seluruh data atas pendaftaran jaminan fidusia, perbaikan sertipikat jaminan fidusia, perubahan sertipikat jaminan fidusia, penghapusan sertipikat jaminan fidusia dan penyimpanan dokumen fisiknya menjadi tanggung jawab penerima fidusia, kuasa atau wakilnya.

\section{Daftar Pustaka}

Nurwidiatmo, 2011, Kompilasi Bidang Hukum Tentang Leasing, Jakarta BPHN.

M. Bahsan, 2008 Hukum Jaminan dan Jaminan Kredit Perbankan Indonesia, Jakarta : Raja Grafindo Persada.

Gunawan Widjaya dan Ahmad Yani. 2001 Jaminan Fidusia, Bandung : Raja Grafindo Persada.

\section{Undang-Undang}

Republik Indonesia, Undang-Undang Dasar Negara Republik Indonesia Tahun 1945

Republik Indonesia, Undang-Undang Nomor 42 Tahun 1999 tentang Jaminan Fidusia

Republik Indonesia, Peraturan Pemerintah Republik
Indonesia Nomor 86 Tahun 2000 tentang Tata Cara Pendaftaran Jaminan Fidusia dan Biaya Pembuatan Akta Jaminan Fidusia

Republik Indonesia, Peraturan Menteri Keuangan Nomor 130 /PMK.010/Tahun 2012 tentang Pendaftaran Jaminan Fidusia bagi Perusahaan Pembiayaan yang melakukan Pembiayaan Konsumen untuk Kendaraan Bermotor dengan Pembebanan Jaminan Fidusia

Republik Indonesia Peraturan Menteri Hukum dan Hak Asasi Manusia Republik Indonesia Nomor 10 Tahun 2013 tentang Tata Cara Pendaftaran Jaminan Fidusia secara elektronik.

Republik Indonesia Peraturan Pemerintah Republik Indonesia Nomor 21 Tahun 2015 Tentang Tata Cara Pendaftaran Jaminan Fidusia dan Biaya Pembuatan Akta Jaminan Fidusia. 